\title{
Хірургічна корекція мітральної недостатності ішемічного генезу в поєднанні з пластикою лівого шлуночка серця
}

\author{
Руденко С. А., Руденко А. В., Йоффе Н. О., Дяченко В. Л. \\ Національний інститут серцево-судинної хірургії імені М. М. Амосова НАМНУ, м. Київ, Україна
}

\begin{abstract}
Резюме. Хронічна ішемічна мітральна регургітація є частим і тяжким ускладненням після інфаркту міокарда. Його патофізіологічні механізми пояснюють ремоделювання лівого шлуночка, індукують змішення папілярних м'язів і змінюють кут нахилу стулок клапана. Наявність ішемічної мітральної недостатності незалежно пов'язана зі смертністю і захворюваністю після інфаркту міокарда. У Національному інституті серцево-судинної хірургії імені М. М. Амосова НАМНУ за останні роки було прооперовано 42 пацієнти, яким виконано поєднані втручання на мітральному клапані та лівому шлуночку серця. Лінійна пластика лівого шлуночка була виконана у 29 (69 \%) випадках, ще 13 (31 \%) хворим проведено пластику лівого шлуночка з плікацією міжшлуночкової перегородки. Найчастішим ускладненням у післяопераційний період була гостра серцево-судинна недостатність, яка виникла у 25 (59,5\%) випадках. Після пластичної корекції мітральної вади вона розвинулася у $6(42,9 \%)$ випадках, а при протезуванні клапана - у $19(67,8 \%)$ хвоpих $(\mathrm{p}>0,05)$. Другим ускладненням за частотою виникнення була дихальна недостатність II-III ступеня. Серед цієї когорти пацієнтів дихальна недостатність у післяопераційний період мала місце у 5 (11,9\%) хворих. Післяопераційна летальність після поєднаної резекції аневризми лівого шлуночка та корекції ішемічної мітральної недостатності становила 9,5 \% (4). Різниця летальності після пластики мітрального клапана $(14,3 \%)$ та протезування клапана $(7,1 \%)$ виявилась статистично недостовірною $(\mathrm{p}>0,05)$. Формування аневризми лівого шлуночка серця в поєднанні з ішемічною мітральною недостатністю обумовлюють значну тяжкість стану хворих. Прогностична летальність (EuroSCORE) у цієї категорії пацієнтів досягла $33,5 \pm 5,4 \%$. Основним фактором, що впливав на рівень післяопераційної летальності є ступінь серцевої недостатності.
\end{abstract}

Ключові слова: ішемічна мітральна недостатність, ішемічна хвороба серия.

Хронічна ішемічна мітральна регургітація є частим і тяжким ускладненням після інфаркту міокарда. Його патофізіологічні механізми пояснюють ремоделювання лівого шлуночка, індукують зміщення папілярних м'язів і змінюють кут нахилу стулок клапана [1]. Наявність ішемічної мітральної недостатності незалежно пов'язана зі смертністю і захворюваністю після інфаркту міокарда [2]. Дисфункція лівого шлуночка виникає у $20 \%$ хворих з хронічною мітральною недостатністю ішемічного генезу, що призводить до погіршення віддалених результатів та виживаності. Дослідження виявили, що 1-річна смертність від тяжкої стадії ішемічної мітральної недостатності сягає $40 \%$, при помірній мітральній недостатності становить $17 \%$, а при легкому ступені $10 \%$. Лікування хронічної ішемічної мітральної недостатності все ще залишається істотною клінічною проблемою [3-6].

Мета роботи. Вивчити результати корекції мітральної недостатності ішемічного генезу в поєднанні 3 пластикою лівого шлуночка серця.

Матеріали та методи дослідження. У Національному інституті серцево-судинної хірургії імені
М. М. Амосова НАМНУ за останні роки було прооперовано 42 пацієнти, яким виконано поєднані втручання на мітральному клапані та лівому шлуночку серця. Хворих чоловічої статі було 33 (78,6\%), а жіночої - 9 $(21,4 \%)$. Згідно з таблицею 1 , жінки були старші за чоловіків ( $65,3 \pm 5,0$ проти $58,5 \pm 8,1$ року), але у вищому функціональному класі за NYHA, ніж чоловіки $(2,2 \pm 0,4$ проти $2,6 \pm 0,7)$. У кожного третього хворого чоловічої статі був в анамнезі цукровий діабет, а серед жінок цей показник становив 44,5\% (4). Незважаючи на те що в чоловіків кількість уражених вінцевих артерій була менша $(2,7 \pm 0,7$ проти $2,9 \pm 0,6)$, скоротлива здатність лівого шлуночка постраждала більше $(33,1 \pm$ $5,9 \%$ та 39,3 \pm 7,4 \% відповідно). Відповідно до зниження скоротливої здатності міокарда лівого шлуночка в чоловіків збільшилась і порожнина лівого шлуночка. Так, кінцевий діастолічний об'єм (КДО) становив $247,8 \pm 50,9$ мл проти $211,2 \pm 38,1$ мл у жінок, а кінцевий систолічний об’ $€$ м (КСО) $-168,0 \pm 39,7$ мл та $129,4 \pm 34,1$ мл відповідно. До I-II класу за NYHА було віднесено 20 (47,6 \%) пацієнтів, а інші 22 (52,4 \%) - до III-IV класу за NYHA. Середній показник Euroscore у пацієнтів цієї групи досягнув $33,5 \pm 5,4 \%$. 


\section{Таблиця 1}

Доопераційна характеристика пацієнтів

\begin{tabular}{lcc} 
& \multicolumn{2}{c}{ Стать } \\
\cline { 2 - 3 } Показник & Чоловіки (n=33) & Жінки (n=9) \\
\hline Вік, роки & $58,5 \pm 8,1$ & $65,3 \pm 5,0$ \\
\hline Клас за NҮНА & $2,6 \pm 0,7$ & $2,2 \pm 0,4$ \\
\hline $\begin{array}{l}\text { Кількість інфарктів } \\
\text { міокарда }\end{array}$ & $1,2 \pm 0,5$ & $1,3 \pm 0,3$ \\
\hline Цукровий діабет & $11(33,3 \%)$ & $4(44,4 \%)$ \\
\hline Кількість уражених & $2,7 \pm 0,7$ & $2,9 \pm 0,6$ \\
вінцевих артерій & $2,4 \pm 0,6$ & $2,2 \pm 0,4$ \\
\hline $\begin{array}{l}\text { Ступінь мітральної } \\
\text { недостатності }\end{array}$ & $247,8 \pm 50,9$ & $211,2 \pm 38,1$ \\
\hline КДО, мл & $168,0 \pm 39,7$ & $129,4 \pm 34,1$ \\
\hline КСО, мл & $83,9 \pm 17,3$ & $83,6 \pm 15,3$ \\
\hline УО, мл & $33,1 \pm 5,9$ & $39,3 \pm 7,4$ \\
\hline Фракція викиду лівого & & \\
шлуночка, \% &
\end{tabular}

Примітка. УО - ударний об’єм.

Результати та обговорення. Усім хворим було виконано корекцію мітральної недостатності та пластику лівого шлуночка серця. Лінійна пластика аневризми лівого шлуночка була виконана у 29 (69 \%) випадках, ще 13 (31\%) хворим проведено пластику лівого шлуночка 3 плікацією міжшлуночкової перегородки. Лінійна пластика лівого шлуночка у 18 (42,9 \%) хворих була доповнена протезуванням мітрального клапана, а в $11(26,2 \%)$ випадках - пластикою мітрального клапана. Пластичне втручання на мітральному клапані разом з лінійною пластикою лівого шлуночка та плікацією міжшлуночкової перегородки було виконано у o $3(7,1 \%)$ пацієнтів, а в $10(23,8 \%)$ операція на лівому шлуночку за цією методикою була доповнена протезуванням мітрального клапана.

Вибір методу корекції мітральної недостатності достовірно не впливав як на час перетискання аорти $(121,8 \pm 24,1$ хв та $123,7 \pm 23,5$ хв) $(\mathrm{p}>0,05)$, так і на тривалість штучного кровообігу загалом $(195,9 \pm 35,5$ хв та $201,3 \pm 55,6$ хв) (p > 0,05). Найчастішим ускладненням у післяопераційний період була гостра серцево-судинна недостатність, яка діагностована у 25 (59,5\%) випадках (таблиця 2). Після пластичної корекції мітральної вади вона виникла у $6(42,9 \%)$ випадках, а при протезуванні клапана - у $19(67,8$ \%) хворих $(\mathrm{p}>0,05)$. Другим за частотою виникнення ускладненням була дихальна недостатність II-III ступеня. Серед цієї когорти пацієнтів дихальна недостатність у післяопераційний період мала місце у 5 (11,9 \%) хворих. Гостре порушення мозкового кровообігу виникло в 1 хворого з групи пластичної корекції мітральної вади, що становило $2,4 \%$. Однак частота виникнення всіх
Таблиця 2

Характеристика періопераційного періоду

\begin{tabular}{|c|c|c|c|}
\hline Показник & $\begin{array}{c}\text { Пластика } \\
\text { мітрального } \\
\text { клапана }\end{array}$ & $\begin{array}{l}\text { Протезування } \\
\text { мітрального } \\
\text { клапана }\end{array}$ & p \\
\hline $\begin{array}{l}\text { Час перетискання } \\
\text { аорти, хв }\end{array}$ & $121,8 \pm 24,1$ & $123,7 \pm 23,5$ & $p>0,05$ \\
\hline $\begin{array}{l}\text { Тривалість штучного } \\
\text { кровообігу }\end{array}$ & $195,9 \pm 35,5$ & $201,3 \pm 55,6$ & $p>0,05$ \\
\hline $\begin{array}{l}\text { Середня кількість } \\
\text { дистальних } \\
\text { анастамозів }\end{array}$ & $3,0 \pm 1,5$ & $2,5 \pm 1,2$ & $p>0,05$ \\
\hline $\begin{array}{l}\text { Гостре порушення } \\
\text { мозкового кровообігу }\end{array}$ & 1 (7,1%) & 0 & $p>0,05$ \\
\hline $\begin{array}{l}\text { Гостра серцево-су- } \\
\text { динна недостатність } \\
\text { II-III ст. }\end{array}$ & $6(42,9 \%)$ & $19(67,8 \%)$ & $p>0,05$ \\
\hline $\begin{array}{l}\text { Дихальна } \\
\text { недостатність II-III ст. }\end{array}$ & $2(14,3 \%)$ & $3(10,7$ \%) & $p>0,05$ \\
\hline Тривалість ШВЛ, год & $46,6 \pm 40,1$ & $25,7 \pm 35,4$ & $p>0,05$ \\
\hline $\begin{array}{l}\text { Тивалість перебу- } \\
\text { вання у відділенні } \\
\text { інтенсивної терапії, } \\
\text { год }\end{array}$ & $169,6 \pm 95,5$ & $149,1 \pm 103,0$ & $p>0,05$ \\
\hline $\begin{array}{l}\text { Тривалість } \\
\text { післяопераційного } \\
\text { періоду, днів }\end{array}$ & $13,5 \pm 4,5$ & $13,2 \pm 7,8$ & $p>0,05$ \\
\hline Летальність & $2(14,3 \%)$ & $2(7,1 \%)$ & $p>0,05$ \\
\hline
\end{tabular}

післяопераційних ускладнень статистично достовірно не залежала від методики корекції мітральної недостатності. Вибір методу хірургічної корекції ішемічної мітральної недостатності не впливав на час перебування у відділенні інтенсивної терапії (169,6 \pm 95,5 год та $149,1 \pm 103,0$ год) (p > 0,05) та стаціонарі загалом. Післяопераційна летальність після поєднаної резекції аневризми лівого шлуночка та корекції ішемічної мітральної недостатності становила 9,5 \% (4). Різниця летальності після пластики мітрального клапана $(14,3 \%)$ та протезування клапана $(7,1 \%)$ виявилась статистично недостовірною ( $\mathrm{p}>0,05)$.

Висновки. Формування аневризми лівого шлуночка серця в поєднанні з ішемічною мітральною недостатністю обумовлюють значну тяжкість стану хворих. Прогностична летальність (EuroSCORE) у цієї категорії пацієнтів $33,5 \pm 5,4 \%$. Основним фактором, що впливав на рівень післяопераційної летальності $є$ ступінь серцевої недостатності.

\section{Список використаних джерел References}

1. Piérard LA, Carabello BA. Ischaemic mitral regurgitation: pathophysiology, outcomes and the conundrum of treatment. Eur Heart J. 2010;31:2996-3005. 
2. Nishimura RA, Otto CM, Bonow RO, Carabello BA, Erwin JP 3rd, Guyton RA, et al; American College of Cardiology/American Heart Association Task Force on Practice Guidelines. 2014 AHA/ACC guideline for the management of patients with valvular heart disease: executive summary: a report of the American College of Cardiology/American Heart Association Task Force on Practice Guidelines. J Am Coll Cardiol 2014;63(22):243888. https://doi.org/10.1016/j.jacc.2014.02.537

3. Saeed G, Gradaus R, Neuzner J. Single coronary artery anomaly without previous myocardial infarction does not cause ischemic mitral insufficiency. Asian Cardiovasc Thorac Ann. 2014;22(8):1011-2.

4. de Cannière D, Vandenbossche JL, Nouar E, Faict S, Falchetti A, Unger P. Clinical implications of preserving subvalvular apparatus during mitral valve replacement for acute ischemic papillary muscle rupture. Ann Thorac Surg. 2016;102: 305-8. https://doi.org/10.1016/j. athoracsur.2015.06.121

5. Bouma W, Wijdh-den Hamer IJ, Koene BM, Kuijpers M, Natour E, Erasmus ME, et al. Long-term survival after mitral valve surgery for post-myocardial infarction papillary muscle rupture. J Cardiothorac Surg 2015; 10:11. https:// doi.org/10.1186/s13019-015-0213-1

6. Goldstein D, Moskowitz AJ, Gelijns AC, Ailawadi G, Parides MK, Perrault LP, et al; CTSN. Two-year outcomes of surgical treatment of severe ischemic mitral regurgitation. N Engl J Med. 2016;374(4):344-53. https:// doi.org/10.1056/NEJMoa1512913

\title{
Surgical Repair of Ischemic Mitral Insufficiency in Combination with Left Ventricle Plasty
}

\author{
Rudenko S. A., Rudenko A. V., Yoffe N. O., Dyachenko V. L.
}

National M. M. Amosov Institute of Cardiovascular Surgery of the National Academy of Medical Sciences of Ukraine, Kyiv, Ukraine

Abstract. Chronic ischemic mitral regurgitation is a frequent and severe complication after myocardial infarction. Its pathophysiological mechanisms explain the left ventricle remodeling, induce the papillary muscles displacement and change the angle of inclination of the valve leaflets. The presence of ischemic mitral insufficiency is independently associated with mortality and morbidity after myocardial infarction. In the recent years, at the National M. M. Amosov Institute of Cardiovascular Surgery, 42 patients underwent surgical combined interventions on the mitral valve and the left ventricle. All the patients underwent left ventricle plasty. The most frequent complication in the postoperative period was acute cardiovascular failure, which occurred in $25(59.5 \%)$ cases: $6(42.9 \%)$ cases after mitral defects plasty and 19 (67.8 \%) patients after the valve replacement. The second most frequent complication was respiratory failure of II-III degree. In this patient cohort, respiratory failure in the postoperative period occurred in $5(11.9 \%)$ patients. Postoperative mortality after combined resection of the left ventricular aneurysm and surgical repair of ischemic mitral insufficiency was $9.5 \%$ (4 cases). The difference in mortality after mitral valve plasty $(14.3 \%)$ and valve replacement $(7.1 \%)$ was statistically insignificant. Left ventricular aneurysm combined with ischemic mitral insufficiency contributes to the severity of the patients' condition. Prognostic mortality (EuroSCORE) in this category of patients is $33.5 \pm 5.4 \%$. Choosing the method for mitral insufficiency surgical repair does not affect postoperative mortality. Mortality is due to the initial severity in this group of patients.

Keywords: ischemic mitral insufficiency, coronary heart disease.

Стаття надійшла в редакцію 18.04.2019 р. 